\title{
Predictors of cardiovascular disease in asthma and chronic obstructive pulmonary disease
}

\author{
Michela Bellocchia', Monica Masoero ${ }^{1}$, Antonio Ciuffreda ${ }^{1}$, Silvia Croce ${ }^{1}$, Arianna Vaudano ${ }^{1}$, Roberto Torchio ${ }^{2}$, \\ Monica Boita ${ }^{1}$ and Caterina Bucca ${ }^{1 *}$
}

\begin{abstract}
Background: Cardiovascular disease (CVD) is a common comorbidity in patients with chronic airway obstruction, and is associated with systemic inflammation and airway obstruction. The aim of this study was to evaluate the predictors of CVD in two different conditions causing chronic airway obstruction, asthma and COPD.

Methods: Lung function tests, clinical and echocardiographic data were assessed in 229 consecutive patients, 100 with asthma and 129 with COPD. CVD was classified into: pressure overload (PO) and volume overload (VO). Sub-analysis of patients with ischemic heart disease (IHD) and pulmonary hypertension (PH) was also performed.

Results: CVD was found in 185 patients (81\%: 51\% COPD and 30\% asthmatics) and consisted of PO in $42 \%$ and of VO in 38\% patients. COPD patients, as compared to asthmatics, had older age, more severe airway obstruction, higher prevalence of males, of smokers, and of CVD (91\% vs 68\%), either PO (46\% vs 38\%) or VO (45\% vs 30\%). CVD was associated with older age and more severe airway obstruction both in asthma and COPD. In the overall patients the predictive factors of CVD were age, COPD, and male sex; those of PO were COPD, BMI, VC, FEV 1 and $\mathrm{MEF}_{50}$ and those of $\mathrm{VO}$ were age, $\mathrm{VC}$ and $\mathrm{MEF}_{50}$. In asthma, the predictors of CVD were $\mathrm{VC}, \mathrm{FEV}_{1}, \mathrm{FEV}_{1} \mathrm{NC} \%$, and $\mathrm{PaO}_{2}$, those of PO were $\mathrm{VC}$, FEV 1 and $\mathrm{FEV}_{1} \mathrm{NC} \%$, while for $\mathrm{VO}$ there was no predictor. In COPD the predictors of CVD were age, GOLD class and sex, those of $\mathrm{VO}$ age, $\mathrm{VC}$ and $\mathrm{MEF}_{50}$, and that of $\mathrm{PO}$ was BMI. Sub-analysis showed that IHD was predicted by COPD, age, BMI and FEV ${ }_{1}$, while PH (found only in 25 COPD patients), was predicted by $\mathrm{VO}$ (present in $80 \%$ of the patients) and $\mathrm{FEV}_{1}$. In subjects aged 65 years or more the prevalence of CVD, PO and VO was similar in asthmatic and COPD patients, but COPD patients had higher prevalence of males, smokers, IHD, PH, lower $\mathrm{FEV}_{1}$ and higher CRP.

Conclusions: The results of this study indicate that cardiovascular diseases are frequent in patients with chronic obstructive disorders, particularly in COPD patients. The strongest predictors of CVD are age and airway obstruction. COPD patients have higher prevalence of ischemic heart disease and pulmonary hypertension. In the elderly the prevalence of $\mathrm{PO}$ and $\mathrm{VO}$ in asthma and COPD patients is similar.
\end{abstract}

Keywords: Airway obstruction, Asthma, Cardiovascular disease, COPD, Pressure overload, Volume overload

\section{Background}

Asthma and chronic obstructive pulmonary disease (COPD) are the most common airway disorders with a high morbidity and mortality $[1,2]$. According to the Global Initiative for Asthma (GINA), approximately 300 millions people suffer from asthma [1] with a prevalence ranging from 1 to $18 \%$. COPD prevalence is around 6\%,

\footnotetext{
* Correspondence: caterina.bucca@unito.it

'Department of Medical Sciences, University of Turin, Via Genova 3, 10126 Turin, Italy

Full list of author information is available at the end of the article
}

but data are highly variable, depending on survey methods and diagnostic criteria [3].

Both asthma and COPD are characterized by inflammation, which in asthma, particularly the eosinophilic phenotype, is predominantly confined to the airway, while in COPD the inflammation may spill-over from the lungs to the systemic circulation and initiate systemic inflammation, as a consequence of exposure to indoor or outdoor air pollution, cigarette smoke, or diesel exhaust fumes [4]. A recent observation indicates that patients with neutrophilic asthma often have systemic

\section{Biomed Central}

(c) 2013 Bellocchia et al.; licensee BioMed Central Ltd. This is an Open Access article distributed under the terms of the Creative Commons Attribution License (http://creativecommons.org/licenses/by/2.0), which permits unrestricted use, distribution, and reproduction in any medium, provided the original work is properly cited. 
inflammation [5]. Elevated serum levels of reactive Creactive protein $(\mathrm{CRP})$ are considered markers of systemic inflammation either in COPD or in asthma [5,6]. Systemic inflammation may be pathogenically related to many of the comorbidities seen in chronic obstructive airway diseases, including cardiovascular disease (CVD). Cardiovascular complications in COPD have been attributed to the systemic effects of smoking [7]. Several observations suggest that reduced pulmonary function, no matter what cause, is associated with increases in myocardial infarction and arrhythmia [8-11]. Forced expiratory volume in one second $\left(\mathrm{FEV}_{1}\right)$ is ranked second to smoking and above blood pressure and cholesterol as a predictor of all-cause and cardiovascular mortality [12]. In this regard, it has been suggested that a reduction in $\mathrm{FEV}_{1}$ combined with smoking history better predicts cardiovascular mortality than cholesterol [13].

The aim of this study was to evaluate prevalence and predictors of CVD in two common airway obstructive diseases with quite different phenotypes, asthma and COPD.

\section{Methods}

Consecutive adults outpatients with asthma and COPD, diagnosed according to international guidelines [1,2], were recruited from those attending the Respiratory Pathophysiology clinic of the University Hospital San Giovanni, Turin, Italy, between January 2011 and June 2012. Inclusion criteria were: age over 40 years, no acute exacerbation of COPD and asthma in the last two months, no active pulmonary tuberculosis or other clinically relevant lung disease. Patients aged below 40 years were excluded because in this age range the risk of COPD is low [14].

\section{Study design}

Patients underwent recording of demographic data including age, full smoking history (current, former and never-smokers), recording of symptoms and medication use, clinical examination, assessment of lung function tests, arterial blood gas analysis and venous blood sampling for serum determination of CRP. Body mass index was calculated on the basis of height and weight (BMI) [15]. Asthma and COPD severity were classified according to GINA [1] and GOLD [2] criteria, respectively. Among COPD patients, those with predominant chronic bronchitis and predominant emphysema were identified.

Coexistent cardiovascular disease was assessed on the basis of history, clinical and echocardiographic data. CVD included: prior myocardial infarction and cardiovascular accidents, documented ischaemic heart disease, pulmonary or systemic arterial hypertension, heart valve disease, echocardiographic diagnosis of pulmonary hypertension.
According to the criteria of the American Heart Association [16], heart disease was classified as follows:

- pressure overload (PO), causing diastolic dysfunction with preserved systolic function, including all the conditions causing concentric left ventricle hypertrophy, such as systemic arterial hypertension and aortic valve disease

- volume overload (VO), including all the conditions causing left ventricle dilatation and systolic dysfunction, such as mitral or aortic incompetence and ischemic heart disease.

Sub-analysis was done on patients with ischemic heart disease (IHD) and pulmonary hypertension (PH).

Lung function tests were measured using the Baires System (Biomedin, Padua, Italy). The values of vital capacity (VC), forced expiratory volume in one second $\left(\mathrm{FEV}_{1}\right)$, and their percentage ratio $\left(\mathrm{FEV}_{1} / \mathrm{VC} \%\right)$, and maximum expiratory flow at mid $\mathrm{VC}\left(\mathrm{MEF}_{50}\right)$ were computed and expressed as percentage of the predicted value, according to the European Respiratory Society guidelines [17].

Arterial blood gases, that is oxygen and carbon dioxide partial pressures $\left(\mathrm{PaO}_{2}\right.$ and $\mathrm{PaCO}_{2}$ respectively) were measured using the analyzer GEM 4000 PREMIERE (Instrumentation Laboratory Lexington USA).

\section{Statistical analysis}

Data were analyzed using the SPSS software package, version 20.0 (SPSS Inc., Chicago, IL, USA) for Windows. Discrete variables are presented as counts and percentages. Continuous variables are presented as means \pm SEM, as appropriate. Comparisons between asthmatics and COPD patients, and between patients with predominant chronic bronchitis and predominant emphysema were performed by the unpaired Student's $t$-test. Comparisons among CVD, PO and VO patients with univariate ANOVA. Nominal variables were compared with the Fisher's exact test and Pearson's $\chi^{2}$. A stepwise backward selection procedure was used to evaluate factors influent on heart disease, using a linear regression models. The models had as dependent variables CVD, PO or VO and as independent predictors: disease (asthma or COPD), age, sex, BMI, smoking habits, GINA or GOLD class, prebronchodilator lung function tests, $\mathrm{PaO}_{2}, \mathrm{CRP}$. The same models were used to evaluate predictors for asthma and COPD separately and for the sub-analysis of patients with IHD or PH.

Statistical significance was assumed at $\mathrm{p}<0.05$.

\section{Results}

The subjects enrolled were 100 asthmatic patients and 129 COPD patients. CVD was found in 185 patients 
Table 1 Comparison between general characteristics of patients with asthma and with COPD

\begin{tabular}{|c|c|c|c|}
\hline & ASTHMA N. 100 & COPD N. 129 & $\mathbf{P}$ \\
\hline Age, years & $59 \pm 1.1$ & $69 \pm 0.9$ & $<0.0001$ \\
\hline $\mathrm{BMI}$ & $25.6 \pm 0.5$ & $26.2 \pm 0.45$ & 0.010 \\
\hline Male, n (\%) & $22(22.0)$ & $78(60.5)$ & $<0.0001$ \\
\hline \multicolumn{4}{|l|}{ Smokers } \\
\hline current, n (\%) & $10(10)$ & $72(55.8)$ & $<0.0001$ \\
\hline past, n (\%) & $8(8)$ & $42(32.6)$ & $<0.0001$ \\
\hline Atopy,n (\%) & $65(73.1)$ & $10(7.7)$ & $<0.0001$ \\
\hline Cardiovascular disease, n (\%) & $68(68)$ & $117(90.7)$ & 0.00002 \\
\hline Pressure overload, n (\%) & $38(38.0)$ & $59(45.7)$ & NS \\
\hline Volume overload, n (\%) & $30(30.0)$ & $58(45.0)$ & 0.021 \\
\hline Subgroup IHD, n (\%) & $8(8.0)$ & $50(38.8)$ & $<0.001$ \\
\hline Subgroup PH, n (\%) & $0(0.0)$ & $25(19.4)$ & $<0.001$ \\
\hline $\mathrm{VC}^{*}, \%$ predicted & $88.9 \pm 1.7$ & $83.6 \pm 1.8$ & 0.033 \\
\hline $\mathrm{FEV}_{1}{ }^{*}, \%$ predicted & $78.0 \pm 2.0$ & $64.6 \pm 1.9$ & $<0.0001$ \\
\hline $\mathrm{FEV}_{1} \mathrm{NC}^{*} \%$ & $65.7 \pm 1.3$ & $57.1 \pm 1.3$ & $<0.0001$ \\
\hline $\mathrm{MEF}_{50} * \%$ predicted & $41.8 \pm 2.4$ & $29.5 \pm 2.1$ & $<0.0001$ \\
\hline $\mathrm{PaO}_{2}, \mathrm{mmHg}$ & $74.5 \pm 1.6$ & $71.4 \pm 1.0$ & NS \\
\hline $\mathrm{PaCO}_{2}, \mathrm{mmHg}$ & $38.4 \pm 0.5$ & $39.8 \pm 0.5$ & NS \\
\hline $\mathrm{CRP}, \mathrm{mg} / \mathrm{ml}$ & $3.4 \pm 0.4$ & $7.6 \pm 0.7$ & $<0.0001$ \\
\hline Beta adrenergic therapy, $\mathrm{n}(\%)$ & $94(94.9)$ & $97(75.2)$ & 0.0001 \\
\hline Corticosteroid therapy, n (\%) & $95(96)$ & $90(69.8)$ & $<0.0001$ \\
\hline Anticholinergic therapy, n (\%) & $22(22)$ & $76(58.9)$ & $<0.0001$ \\
\hline
\end{tabular}

Value recorded before bronchodilator.

(81\%), and consisted of pressure overload in 97 (42\%) and of volume overload in $88(38 \%)$. IHD was found in 58 patients (25\%), 8 asthmatics and 50 COPD, and $\mathrm{PH}$ in $25(11 \%)$, all with COPD. The general characteristics of asthmatic and COPD patients are compared in Table 1. The COPD group was older, and had higher prevalence of men and of both present and past smokers, more severe airway obstruction and higher prevalence of heart disease, including PO, VO, IHD and $\mathrm{PH}$. Moreover, COPD patients had higher CRP values than asthmatics, suggestive of systemic inflammation. No significant difference in $\mathrm{PaO}_{2}$ and $\mathrm{PaCO}_{2}$ was found between the two groups.

The comparisons among subgroups with no cardiovascular disease (No CVD), with PO and VO in the overall patients, in asthma and in COPD are reported in the Tables 2, 3 and 4 .

In the overall patients (Table 2), both $\mathrm{PO}$ and VO, as compared with no CVD, were associated with older age and lower $\mathrm{VC}, \mathrm{FEV}_{1}, \mathrm{FEV}_{1} / \mathrm{VC}$ and $\mathrm{MEF}_{50}$ and higher

Table 2 Comparisons among patients without cardiovascular disease (no CVD), with pressure overload (PO) and volume overload (VO) in the overall study population

\begin{tabular}{|c|c|c|c|c|c|c|c|}
\hline ASTHMA + COPD & no CVD N. 44 & PO N. 97 & VO N. 88 & Univariate ANOVA & no CVD vs PO & no CVD vs VO & PO vs VO \\
\hline Age, years & $53.3 \pm 1.3$ & $64.3 \pm 1.0$ & $69.1 \pm 1.1$ & $<0.0001$ & $<0.0001$ & $<0.0001$ & 0.002 \\
\hline Male, n (\%) & $18(40.9)$ & $43(44.3)$ & $39(44.3)$ & NS & NS & NS & NS \\
\hline $\mathrm{BMI}$ & $24.7 \pm 0.7$ & $26.9 \pm 0.6$ & $25.5 \pm 0.5$ & 0.038 & 0.028 & NS & NS \\
\hline VC, \% pred. & $93.4 \pm 2.2$ & $85.1 \pm 1.7$ & $83.5 \pm 2.4$ & 0.011 & 0.005 & 0.006 & NS \\
\hline $\mathrm{FEV}_{1}, \%$ pred. & $82.6 \pm 2.5$ & $70.7 \pm 2.1$ & $64.8 \pm 2.4$ & $<0.0001$ & 0.001 & $<0.0001$ & NS \\
\hline $\mathrm{FEV}_{1} / \mathrm{NC} \%$ & $67.6 \pm 1.7$ & $61.5 \pm 1.5$ & $56.7 \pm 1.6$ & $<0.0001$ & 0.015 & $<0.0001$ & 0.032 \\
\hline $\mathrm{MEF}_{50}, \%$ pred & $49.5 \pm 4.1$ & $35.8 \pm 2.3$ & $25.8 \pm 2.3$ & $<0.0001$ & 0.002 & $<0.0001$ & 0.003 \\
\hline $\mathrm{CRP}, \mathrm{mg} / \mathrm{ml}$ & $3.1 \pm 0.6$ & $5.9 \pm 0.6$ & $7.3 \pm 1.0$ & 0.011 & 0.009 & 0.007 & NS \\
\hline
\end{tabular}

NS not statistically significant. 
Table 3 Comparisons among patients without cardiovascular disease (no CVD), with pressure overload (PO) and volume overload (VO) in asthma

\begin{tabular}{|c|c|c|c|c|c|c|c|}
\hline ASTHMA & no CVD N. 32 & PO N. 38 & VO N. 30 & Univariate ANOVA & no CVD vs PO & no CVD vs Vo & PO vs VO \\
\hline Age, years & $51.3 \pm 1.4$ & $60.7 \pm 1.6$ & $63.1 \pm 2.1$ & $<0.0001$ & $<0.0001$ & $<0.0001$ & NS \\
\hline Male, n (\%) & $9(28.1)$ & $6(15.8)$ & $7(23.3)$ & NS & NS & NS & NS \\
\hline BMl & $24.5 \pm 0.8$ & $26.5 \pm 0.9$ & $25.7 \pm 0.7$ & NS & NS & NS & NS \\
\hline VC, \% pred. & $94.0 \pm 2.8$ & $84.7 \pm 2.2$ & $89.0 \pm 3.7$ & NS & 0.011 & NS & NS \\
\hline $\mathrm{FEV}_{1}, \%$ pred. & $85.4 \pm 2.9$ & $76.7 \pm 2.9$ & $73.8 \pm 4.5$ & 0.029 & 0.041 & 0.032 & NS \\
\hline $\mathrm{FEV}_{1}$ NC \% & $68.9 \pm 1.7$ & $65.7 \pm 2.0$ & $61.2 \pm 2.9$ & 0.042 & NS & 0.010 & NS \\
\hline $\mathrm{MEF}_{50}, \%$ pred & $51.3 \pm 4.2$ & $37.8 \pm 3.5$ & $35.8 \pm 4.5$ & 0.017 & 0.016 & 0.015 & NS \\
\hline $\mathrm{CRP}, \mathrm{mg} / \mathrm{ml}$ & $2.5 \pm 0.5$ & $4.1 \pm 0.8$ & $3.5 \pm 0.8$ & NS & NS & NS & NS \\
\hline
\end{tabular}

CRP. The same associations (apart from CRP) were found in asthmatic patients (Table 3). In COPD patients (Table 4) the significant associations were with age and $\mathrm{MEF}_{50}, \%$.

The results of linear regression analysis are shown in Table 5 for the whole patients, in Table 6 for asthmatic patients and in Table 7 for COPD patients. In the overall patients predictive factors of CVD were: age, COPD, and sex; those of $\mathrm{PO}$ were COPD, BMI, VC, $\mathrm{FEV}_{1}$ and $\mathrm{MEF}_{50}$ and those of $\mathrm{VO}$ were age, class of disease severity, $\mathrm{VC}$ and $\mathrm{MEF}_{50}$. In asthma, the strongest predictors of CVD were $\mathrm{VC}, \mathrm{FEV}_{1}$ and $\mathrm{FEV}_{1} / \mathrm{VC} \%$, and $\mathrm{PaO}_{2}$, those of $\mathrm{PO}$ were $\mathrm{VC}, \mathrm{FEV}_{1}$ and $\mathrm{FEV}_{1} / \mathrm{VC} \%$; no predictor was found for VO. In COPD the predictors of CVD were age, GOLD class and sex; those of VO were age, $\mathrm{VC}$ and $\mathrm{MEF}_{50}$, while the only predictor of $\mathrm{PO}$ was BMI.

As shown in Table 8, the predictors of IHD were COPD, age, BMI and $\mathrm{FEV}_{1}$ and those of $\mathrm{PH}$, found only in COPD patients, were $\mathrm{VO}$ (present in $80 \%$ of the patients) and $\mathrm{FEV}_{1}$

The distributions of $\mathrm{PO}$ and $\mathrm{VO}$ by severity of asthma (GINA) and COPD (GOLD) are reported in Figure 1. In asthma, there is a clear increase in the prevalence of both $\mathrm{PO}$ and $\mathrm{VO}$ with increasing the severity class, while in COPD the prevalence of each type of CVD is similar in all classes. The comparison between chronic bronchitis and emphysema patients, shown in Table 9, showed that the latter ones had older age, lower BMI, more severe airway obstruction and higher prevalence of heart volume overload and of pulmonary hypertension.

As one of the stronger predictors of CVD was age, we made a sub-analysis on subjects with an age equal to 65 years or higher. As shown in Table 10, the prevalence of CVD, PO and VO was similar in asthmatic and COPD patients; the latter had higher prevalence of men, smokers, lower $\mathrm{FEV}_{1}$, higher CRP and of IHD and PH. The results of linear regression analysis in these older patients are reported in Tables 11, 12 and 13.

\section{Discussion}

The results of this study show that patients with chronic airway obstructive disorders, either asthma or COPD, have increased prevalence of cardiovascular diseases as compared to the general population of similar age [18]. The comparison between the two disorders, (see Table 1) showed that CVD, particularly with volume overload, was more frequent in COPD patients, who had also older age, higher BMI, heavy smoking history, increased CRP and greater airway obstruction. This finding is in agreement with prior observations that in COPD comorbidities are frequent and are sustained by systemic

Table 4 Comparisons among patients without cardiovascular disease (no CVD), with pressure overload (PO) and volume overload (VO) in COPD

\begin{tabular}{|c|c|c|c|c|c|c|c|}
\hline COPD & no CVD N. 12 & PO N. 59 & VO N. 58 & Univariate ANOVA & no CVD vs PO & no CVD vs VO & PO vs VO \\
\hline Age, years & $58.5 \pm 2.6$ & $66.7 \pm 1.3$ & $72.4 \pm 1.0$ & $<0.0001$ & 0.012 & $<0.0001$ & 0.001 \\
\hline Male, n (\%) & $9(75)$ & $37(62.7)$ & $32(55.2)$ & NS & NS & NS & NS \\
\hline BMl & $25.4 \pm 1.5$ & $27.1 \pm 0.7$ & $25.4 \pm 0.6$ & NS & NS & NS & NS \\
\hline VC, \% pred. & $91.8 \pm 3.12$ & $85.3 \pm 2.4$ & $80.0 \pm 2.9$ & NS & NS & NS & NS \\
\hline $\mathrm{FEV}_{1}, \%$ pred & $75.2 \pm 4.8$ & $66.3 \pm 2.8$ & $60.1 \pm 2.8$ & 0.048 & NS & 0.023 & NS \\
\hline $\mathrm{FEV}_{1}$ NC \% & $61.5 \pm 3.8$ & $58.8 \pm 2.0$ & $54.4 \pm 1.9$ & NS & NS & NS & NS \\
\hline $\mathrm{MEF}_{50}, \%$ pred & $44.6 \pm 10.2$ & $34.5 \pm 3.1$ & $20.18 \pm 2.1$ & $<0.0001$ & NS & $<0.0001$ & $<0.0001$ \\
\hline $\mathrm{CRP}, \mathrm{mg} / \mathrm{ml}$ & $4.4 \pm 1.4$ & $7.0 \pm 0.9$ & $8.9 \pm 1.4$ & NS & NS & NS & NS \\
\hline
\end{tabular}


Table 5 Results of linear regression analysis for predictors of cardiovascular disease (CVD) in the overall patients

\begin{tabular}{|c|c|c|c|c|c|}
\hline \multirow[t]{2}{*}{ Asthma + COPD } & \multicolumn{2}{|c|}{ Non standardized coefficients } & \multirow{2}{*}{$\begin{array}{c}\text { Standardized coefficient } \\
\beta\end{array}$} & \multirow[t]{2}{*}{$\mathbf{t}$} & \multirow[t]{2}{*}{ Sig } \\
\hline & B & SD Error & & & \\
\hline \multicolumn{6}{|l|}{ CVD } \\
\hline Constant & .948 & .248 & & 3.829 & .000 \\
\hline Age & .012 & .003 & .340 & 4.357 & .000 \\
\hline COPD & .137 & .063 & .169 & 2.195 & .030 \\
\hline Sex & .116 & .058 & .144 & 1.991 & .048 \\
\hline VC, \% pred & -.003 & .002 & -.124 & -1.784 & .076 \\
\hline $\mathrm{MEF}_{50}, \%$ pred & -.002 & .001 & -.131 & -1.728 & .086 \\
\hline \multicolumn{6}{|l|}{ Pressure overload } \\
\hline Constant & 1.066 & .264 & & 4.031 & .000 \\
\hline COPD & .217 & .074 & .225 & 2.939 & .004 \\
\hline BMI & .017 & .007 & .183 & 2.482 & .014 \\
\hline VC, \% pred & -.006 & .003 & -.213 & -2.031 & .044 \\
\hline $\mathrm{FEV}_{1}, \%$ pred & .007 & .003 & .322 & 2.162 & .032 \\
\hline $\mathrm{MEF}_{50}, \%$ pred & -.006 & .002 & -.305 & -2.668 & .008 \\
\hline \multicolumn{6}{|l|}{ Volume Overload } \\
\hline Constant & 1.318 & .446 & & 2.954 & .004 \\
\hline Age & .015 & .004 & .310 & 3.529 & .001 \\
\hline GINA/GOLD class & -.118 & .056 & -.227 & -2.113 & .037 \\
\hline VC, \% pred & -.006 & .003 & -.197 & -2.244 & .027 \\
\hline $\mathrm{MEF}_{50}, \%$ pred & -.005 & .002 & -.227 & -2.094 & .038 \\
\hline
\end{tabular}

Table 6 Results of linear regression analysis for predictors of cardiovascular diseases (CVD) in asthma

\begin{tabular}{|c|c|c|c|c|c|}
\hline \multirow[t]{2}{*}{ ASTHMA } & \multicolumn{2}{|c|}{ Non standardized coefficients } & \multirow{2}{*}{$\begin{array}{c}\text { Standardized coefficient } \\
\beta\end{array}$} & \multirow[t]{2}{*}{$\mathbf{t}$} & \multirow[t]{2}{*}{ Sig } \\
\hline & B & SD Error & & & \\
\hline \multicolumn{6}{|l|}{ CVD } \\
\hline Constant & 8.291 & 1.056 & & 7.851 & .000 \\
\hline Age & -.009 & .005 & -.270 & -1.981 & .059 \\
\hline BMI & .016 & .008 & .223 & 1.874 & .073 \\
\hline VC, \% pred & -.060 & .009 & -2.402 & -6.630 & .000 \\
\hline $\mathrm{FEV}_{1}, \%$ pred & .073 & .011 & 3.667 & 6.894 & .000 \\
\hline $\mathrm{FEV}_{1} / \mathrm{NC}, \%$ & -.094 & .013 & -3.499 & -7.021 & .000 \\
\hline $\mathrm{PaO}_{2}$ & -.010 & .005 & -.278 & -2.268 & .033 \\
\hline PRC & .016 & .009 & .209 & 1.797 & .085 \\
\hline \multicolumn{6}{|c|}{ Pressure Overload } \\
\hline Constant & 6.668 & 1.082 & & 6.163 & .000 \\
\hline VC, \% pred & -.060 & .012 & -1.874 & -5.078 & .000 \\
\hline $\mathrm{FEV}_{1}, \%$ pred & .067 & .013 & 2.626 & 5.107 & .000 \\
\hline $\mathrm{FEV}_{1} / \mathrm{NC}, \%$ & -.077 & .016 & -2.237 & -4.690 & .000 \\
\hline \multicolumn{6}{|c|}{ Volume Overload } \\
\hline Constant & -.116 & .693 & & -.167 & .869 \\
\hline Age & .019 & .011 & .320 & 1.822 & .079 \\
\hline
\end{tabular}


Table 7 Results of linear regression analysis for predictors of cardiovascular diseases (CVD) in COPD

\begin{tabular}{|c|c|c|c|c|c|}
\hline \multirow[t]{2}{*}{ COPD } & \multicolumn{2}{|c|}{ Non standardized coefficients } & \multirow{2}{*}{$\begin{array}{c}\text { Standardized coefficient } \\
\beta\end{array}$} & \multirow[t]{2}{*}{$\mathbf{t}$} & \multirow[t]{2}{*}{ Sig. } \\
\hline & B & SD Error & & & \\
\hline \multicolumn{6}{|l|}{ CVD } \\
\hline Constant & .686 & .393 & & 1.747 & .084 \\
\hline Age & .007 & .003 & .228 & 2.143 & .035 \\
\hline GOLD Class & .076 & .036 & .241 & 2.089 & .040 \\
\hline Sex & .121 & .061 & .203 & 1.983 & .050 \\
\hline $\mathrm{PaO}_{2}$ & .006 & .003 & .209 & 1.826 & .071 \\
\hline \multicolumn{6}{|c|}{ Pressure Overload } \\
\hline Constant & 1.237 & .229 & & 5.414 & .000 \\
\hline BMI & .020 & .008 & .244 & 2.337 & .022 \\
\hline \multicolumn{6}{|l|}{ Volume Overload } \\
\hline Constant & 1.317 & .519 & & 2.539 & .013 \\
\hline Age & .017 & .005 & .334 & 3.311 & .001 \\
\hline VC, \% pred & -.006 & .003 & -.220 & -2.076 & .041 \\
\hline $\mathrm{MEF}_{50} \%$ pred & -.006 & .003 & -.305 & -2.351 & .021 \\
\hline
\end{tabular}

inflammation and by smoking [4,6,7]. The comparison among patients without CVD, with $\mathrm{PO}$ and VO, showed that both pressure and volume overload were associated with older age and increased airway obstruction, either in asthma or in COPD, (see Tables 2, 3 and 4). These findings are in agreement with prior observations in COPD [8-13,19]. Unfortunately, relatively little research has been done in asthma [14]. It is generally believed that the link between asthma and CVD is less strong than that for COPD $[14,20,21]$ and this applies particularly to ischemic heart disease in asthmatic males. By contrast, in women adult-onset asthma has been found to be a significant risk factor for IHD and stroke $[21,22]$. Although only 8 of our asthmatic patients had IHD, as many as 6 of them (75\%) were never smoking women. However, the strongest predictors of IHD were COPD, age, BMI and $\mathrm{FEV}_{1}$, as previously suggested $[19,23]$. The strong association of COPD with IHD is attributed to the effect of cigarette smoking [19-24], and about $90 \%$ of our COPD patients were past or present smokers. The subanalysis of COPD patients with predominant chronic bronchitis or emphysema, (see Table 9), showed that the emphysema phenotype was associated with older age, lower BMI, more severe airway obstruction and higher

Table 8 Results of linear regression analysis for predictors of ischemic heart disease (IHD) and pulmonary hypertension (PH)

\begin{tabular}{|c|c|c|c|c|c|}
\hline \multirow[t]{2}{*}{ IHD } & \multicolumn{2}{|c|}{ Non standardized coefficients } & \multirow{2}{*}{$\begin{array}{c}\text { Standardized coefficient } \\
\beta\end{array}$} & \multirow[t]{2}{*}{$\mathbf{t}$} & \multirow[t]{2}{*}{ Sig. } \\
\hline & B & SD Error & & & \\
\hline \multicolumn{6}{|l|}{$\mathrm{HD}$} \\
\hline Constant & -1.486 & .667 & & -2.229 & .028 \\
\hline COPD & .450 & .134 & .412 & 3.351 & .001 \\
\hline Age & .012 & .004 & .246 & 2.834 & .005 \\
\hline $\mathrm{BMI}$ & .016 & .008 & .177 & 2.095 & .038 \\
\hline $\mathrm{FEV}_{1}, \%$ pred & .007 & .003 & .309 & 2.127 & .036 \\
\hline GOLD class & .150 & .083 & .294 & 1.810 & .073 \\
\hline \multicolumn{6}{|l|}{$\mathrm{PH}$} \\
\hline Constant & 1.127 & .244 & & 4.613 & .000 \\
\hline VO & .246 & .045 & .442 & 5.468 & .000 \\
\hline GOLD class & -.105 & .041 & -.273 & -2.584 & .011 \\
\hline $\mathrm{FEV}_{1}, \%$ pred & -.004 & .002 & -.239 & -2.222 & .028 \\
\hline
\end{tabular}



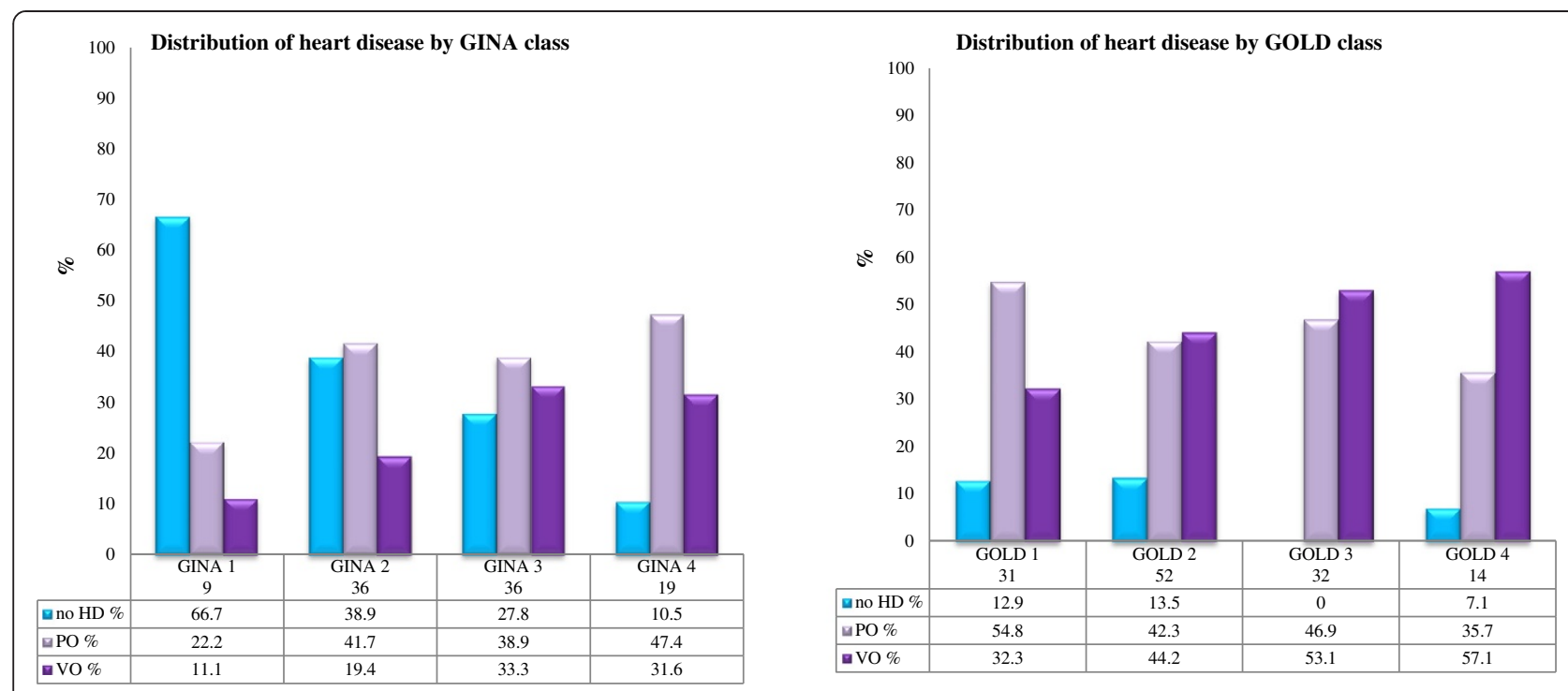

Figure 1 Distributions of heart pressure overload (PO) and volume overload (VO) by GINA asthma severity class (left graph), and by GOLD COPD severity class (right graph).

Table 9 Comparison between general characteristics of patients with chronic bronchitis and emphysema

\begin{tabular}{|c|c|c|c|}
\hline & $\begin{array}{c}\text { Chronic bronchitis } \\
\text { N. } 102\end{array}$ & $\begin{array}{c}\text { Emphysema } \\
\text { N. } 27\end{array}$ & $\mathbf{P}$ \\
\hline Age, years & $68 \pm 1.0$ & $73 \pm 1.5$ & 0.017 \\
\hline BMI & $27.2 \pm 0.5$ & $22.1 \pm 0.6$ & $<0.0001$ \\
\hline Male, n (\%) & $58(56.9)$ & $20(74.1)$ & NS \\
\hline \multicolumn{4}{|l|}{ Smokers } \\
\hline current, n (\%) & $55(53.9)$ & $17(63)$ & NS \\
\hline past, n (\%) & $33(32.4)$ & $9(33.3)$ & NS \\
\hline Cardiovascular disease, n (\%) & $92(90.2)$ & 25 (92.6) & NS \\
\hline Pressure overload,n (\%) & $51(50)$ & $8(29.6)$ & NS \\
\hline Volume overload, n (\%) & $41(40.2)$ & $17(63)$ & 0.034 \\
\hline Subgroup IHD n (\%) & $39(39.4)$ & $11(40.7)$ & NS \\
\hline Subgroup PH n (\%) & $15(4.7)$ & $10(37)$ & 0.009 \\
\hline \multicolumn{4}{|l|}{ GOLD class } \\
\hline 1 & $30(29.4)$ & $1(3.7)$ & 0.005 \\
\hline 2 & $44(43.1)$ & $8(29.6)$ & NS \\
\hline 3 & 19 (18.6) & $13(48.1)$ & 0.0016 \\
\hline 4 & $9(8.8)$ & $5(18.5)$ & NS \\
\hline VC, \% predicted & $82.7 \pm 2$ & $85.5 \pm 4.3$ & NS \\
\hline $\mathrm{FEV}_{1}, \%$ predicted & $68.1 \pm 2.2$ & $51.9 \pm 3.1$ & 0.001 \\
\hline $\mathrm{FEV}_{1}$ NC \% & $60.2 \pm 1.4$ & $46.56 \pm 2.6$ & $<0.0001$ \\
\hline $\mathrm{MEF}_{50}, \%$ predicted & $33.7 \pm 2.5$ & $13.6 \pm 2.1$ & $<0.0001$ \\
\hline $\mathrm{PaO}_{2}, \mathrm{mmHg}$ & $71.2 \pm 1.1$ & $70.1 \pm 2.1$ & NS \\
\hline $\mathrm{PaCO}_{2}, \mathrm{mmHg}$ & $40.1 \pm 0.6$ & $39.0 \pm 0.8$ & NS \\
\hline $\mathrm{CRP}, \mathrm{mg} / \mathrm{ml}$ & $7.9 \pm 1.0$ & $6.8 \pm 1.2$ & NS \\
\hline
\end{tabular}


Table 10 Comparisons between general characteristics of patients 65 years old or more

\begin{tabular}{|c|c|c|c|}
\hline & ASTHMA N. 33 & COPD N. 92 & $\mathbf{P}$ \\
\hline Age, years & $71.8 \pm 0.8$ & $73.6 \pm 0.6$ & NS \\
\hline Male, n (\%) & $5(15.2)$ & $60(65.2)$ & $<0.0001$ \\
\hline \multicolumn{4}{|l|}{ Smokers } \\
\hline Current n(\%) & $4(13)$ & $45(51)$ & $<0.0001$ \\
\hline Past n (\%) & $4(13)$ & $36(41)$ & $<0.0001$ \\
\hline BMI & $25.8 \pm 0.8$ & $26.2 \pm 0.5$ & NS \\
\hline CVD, n (\%) & $30(90.9)$ & 87 (94.6) & NS \\
\hline Pressure overload, n (\%) & $15(45.5)$ & $38(41.3)$ & NS \\
\hline Volume overload, n (\%) & $15(45.5)$ & $49(53.3)$ & NS \\
\hline Ischemic heart disease, n (\%) & $6(18.2)$ & $42(46.7)$ & 0.0054 \\
\hline Pulmonary hypertension, n (\%) & 0 & $21(22.8)$ & 0.0026 \\
\hline VC, \% predicted & $86.1 \pm 2.6$ & $82.7 \pm 2.2$ & NS \\
\hline $\mathrm{FEV}_{1}, \%$ predicted & $73.3 \pm 3.3$ & $63.5 \pm 2.3$ & 0.023 \\
\hline $\mathrm{FEV}_{1}$ NC \% & $61.63 \pm 2.5$ & $56.4 \pm 1.5$ & NS \\
\hline $\mathrm{MEF}_{50}, \%$ predicted & $30.8 \pm 3.4$ & $26.6 \pm 2.3$ & NS \\
\hline CRP, mg/l & $4.1 \pm 0.7$ & $8.2 \pm 1.0$ & 0.018 \\
\hline
\end{tabular}

prevalence of pulmonary hypertension and of volume overload. Unfortunately, there are no data in the literature comparing CVD in the two COPD phenotypes.

As mentioned above, age and COPD were the strongest predictors of CVD, but the two factors were closely linked each other, as COPD patients were significantly older than asthmatics. To clarify this point, we performed a sub-analysis on patients with an age equal to or higher than 65 years. As shown in Table 10, older asthmatics had the same prevalence of CVD than COPD patients (91\% versus 95\%). However, also in the elderly, the prevalence of IHD and $\mathrm{PH}$ was higher in COPD. Pulmonary hypertension deserves a special comment. $\mathrm{PH}$ in COPD is classically attributed to severe hypoxia causing raised pulmonary pressures, but other factors such as endothelial dysfunction or left heart disease, are

Table 11 Results of linear regression analysis for predictors of cardiovascular disease in the overall patients 65 years old or more

\begin{tabular}{|c|c|c|c|c|c|}
\hline \multirow[t]{2}{*}{ Asthma + COPD } & \multicolumn{2}{|c|}{ Non standardized coefficients } & \multirow{2}{*}{$\begin{array}{c}\text { Standardized coefficient } \\
\beta\end{array}$} & \multirow[t]{2}{*}{$t$} & \multirow[t]{2}{*}{ Sig. } \\
\hline & B & SD Error & & & \\
\hline \multicolumn{6}{|l|}{$\overline{C V D}$} \\
\hline Constant & .879 & .421 & & 2.087 & .040 \\
\hline Age & .020 & .006 & .380 & 3.581 & .001 \\
\hline VC, \% predicted & -.005 & .002 & -.308 & -2.813 & .006 \\
\hline CRP & -.006 & .003 & -.190 & -1.707 & .092 \\
\hline \multicolumn{6}{|l|}{ Pressure overload } \\
\hline Constant & .895 & .328 & & 2.731 & .008 \\
\hline Sex & .217 & .094 & .255 & 2.310 & .024 \\
\hline $\mathrm{BMI}$ & .022 & .011 & .226 & 2.047 & .044 \\
\hline \multicolumn{6}{|l|}{ Volume overload } \\
\hline Constant & .293 & .874 & & .335 & .739 \\
\hline Age & .024 & .011 & .229 & 2.091 & .040 \\
\hline VC, \% predicted & -.006 & .003 & -.207 & -1.883 & .063 \\
\hline
\end{tabular}


Table 12 Results of linear regression analysis for predictors of cardiovascular disease in asthmatic patients 65 years old or more

\begin{tabular}{|c|c|c|c|c|c|}
\hline \multirow[t]{2}{*}{ Asthma } & \multicolumn{2}{|c|}{ Non standardized coefficients } & \multirow{2}{*}{$\begin{array}{c}\text { Standardized coefficient } \\
\beta\end{array}$} & \multirow[t]{2}{*}{$\mathrm{t}$} & \multirow[t]{2}{*}{ Sig } \\
\hline & B & SD Error & & & \\
\hline \multicolumn{6}{|l|}{ CVD } \\
\hline Constant & 7.203 & .662 & & 10.885 & .000 \\
\hline VC, \% pred & -.058 & .007 & -2.909 & -8.345 & .000 \\
\hline $\mathrm{FEV}_{1}, \%$ pred & .064 & .008 & 4.069 & 7.728 & .000 \\
\hline $\mathrm{FEV}_{1} / \mathrm{NC}, \%$ & -.084 & .011 & -3.472 & -7.509 & .000 \\
\hline \multicolumn{6}{|c|}{ Pressure overload } \\
\hline Constant & 3.616 & 1.487 & & 2.432 & .035 \\
\hline Age & .028 & .015 & .250 & 1.913 & .085 \\
\hline Sex & .864 & .152 & .864 & 5.691 & .000 \\
\hline GINA class & -.380 & .138 & -.629 & -2.766 & .020 \\
\hline VC, \% pred & -.032 & .010 & -1.209 & -3.306 & .008 \\
\hline $\mathrm{FEV}_{1}, \%$ pred & .033 & .012 & 1.566 & 2.661 & .024 \\
\hline $\mathrm{FEV}_{1} / \mathrm{NC}, \%$ & -.043 & .015 & -1.333 & -2.785 & .019 \\
\hline $\mathrm{PaO}_{2}$ & -.017 & .006 & -.392 & -2.954 & .014 \\
\hline \multicolumn{6}{|c|}{ Volume overload } \\
\hline Constant & .293 & .874 & & .335 & .739 \\
\hline Age & .024 & .011 & .229 & 2.091 & .040 \\
\hline
\end{tabular}

deemed to play a role [24]. In our patients, the predictors of $\mathrm{PH}$ were $\mathrm{FEV}_{1}$ and volume overload, suggesting that both airway obstruction and post capillary mechanisms participated in increased pulmonary vascular resistance. Actually, VO was present in $80 \%$ of patients with $\mathrm{PH}$.

\section{Conclusions}

In conclusion, the results of this study indicate that cardiovascular disease are frequent in patients with chronic obstructive disorders, particularly COPD. The strongest predictors of CVD are age and severity of airway obstruction. In older patients the prevalence of CVD is

Table 13 Results of linear regression analysis for predictors of cardiovascular disease in COPD patients 65 years old or more

\begin{tabular}{|c|c|c|c|c|c|}
\hline \multirow[t]{2}{*}{$\overline{\text { COPD }}$} & \multicolumn{2}{|c|}{ Non standardized coefficients } & \multirow{2}{*}{$\begin{array}{c}\text { Standardized coefficient } \\
\beta\end{array}$} & \multirow[t]{2}{*}{$\mathrm{t}$} & \multirow[t]{2}{*}{ Sig } \\
\hline & B & SD Error & & & \\
\hline \multicolumn{6}{|l|}{ CVD } \\
\hline Constant & .542 & .464 & & 1.169 & .247 \\
\hline Age & .018 & .006 & .373 & 3.259 & .002 \\
\hline BMI & .011 & .006 & .200 & 1.748 & .085 \\
\hline VC,\% predicted & -.003 & .002 & -.198 & -1.724 & .090 \\
\hline \multicolumn{6}{|l|}{ Pressure overload } \\
\hline Constant & 1.110 & .330 & & 3.366 & .001 \\
\hline BMI & .025 & .012 & .263 & 2.060 & .044 \\
\hline \multicolumn{6}{|l|}{ Volume overload } \\
\hline Constant & .928 & .480 & & 1.932 & .058 \\
\hline Sex & .384 & .148 & .341 & 2.598 & .012 \\
\hline Smoking & .289 & .112 & .339 & 2.576 & .013 \\
\hline VC, \% predicted & -.006 & .004 & -.212 & -1.763 & .083 \\
\hline
\end{tabular}


similar in asthma and COPD, apart from ischemic heart disease and pulmonary hypertension, which are strongly associated with COPD.

\section{Abbreviations}

COPD: Chronic obstructive pulmonary disease; CVD: Cardiovascular disease: FEV ${ }_{1}$ : Forced expiratory volume in one second; IHD: Ischemic heart disease; $\mathrm{MEF}_{50}$ : Maximum expiratory flow at mid VC; PH: Pulmonary hypertension; PO: Heart pressure overload; VO: Heart volume overload; VC: Vital capacity.

\section{Competing interests}

The authors declare that they have no competing interests.

\section{Authors' contributions}

$\mathrm{BC}, \mathrm{BM}$ and $\mathrm{MM}$ conceived and designed the study and contributed to drafting the manuscript, BM, MM, CA, CS, VA, BM contributed to acquisition and analysis of data, TR provided critical revision of the manuscript. All authors read and approved the final manuscript.

\section{Author details}

'Department of Medical Sciences, University of Turin, Via Genova 3, 10126 Turin, Italy. ${ }^{2}$ Cardiorespiratory Pathophysiology Department, AOU S, Luigi,

Gonzole Region 10, 10043 Orbassano, Turin, Italy.

Received: 21 May 2013 Accepted: 29 July 2013

Published: 3 September 2013

\section{References}

1. Global initiative for Asthma (GINA). Updated 2012. www.ginasthma.org.

2. The Global Initiative for Chronic Obstructive Lung Disease (GOLD). Global strategy for the diagnosis, management, and prevention of chronic obstructive pulmonary disease. Updated 2013. www.goldcopd.org.

3. Halbert RJ, Natoli JL, Gano A, Badamgarav E, Buist AS, Mannino DM: Global burden of COPD: systematic review and meta-analysis. Eur Respir J 2006, 28:523-532.

4. Sin DD, Wu L, Man SF: The relationship between reduced lung function and cardiovascular mortality: a population-based study and a systematic review of the literature. Chest 2005, 127:1952-1959.

5. Wood LG, Baines KJ, Fu J, Scott HA, Gibson PG: The Neutrophilic Inflammatory Phenotype Is Associated With Systemic Inflammation in Asthma. Chest 2012, 142:86-93.

6. Pinto-Plata VM, Mullerova H, Toso JF, Feudjo-Tepie M, Soriano JB, Vessey RS, Celli BR: C-reactive protein in patients with COPD, control smokers and non-smokers. Thorax 2006, 61:23-28.

7. Yanbaeva DG, Dentener MA, Creutzberg EC, Wesseling G, Wouters EF: Systemic effects of smoking. Chest 2007, 131:1557-1566.

8. Friedman GD, Klatsky AL, Siegelaub AB: Lung function and risk of myocardial infarction and sudden cardiac death. N Engl J Med 1976, 294:1071-1075.

9. Ebi-Kryston KL, Hawthorne VM, Rose G, Shipley MJ, Gillis CR, Hole DJ, Carmen W, Eshleman S, Higgins MW: Breathlessness, chronic bronchitis and reduced pulmonary function as predictors of cardiovascular disease mortality among men in England, Scotland and the United States. Int J Epidemiol 1989, 18:84-88.

10. Ebi-Kryston KL: Respiratory symptoms and pulmonary function as predictors of 10-year mortality from respiratory disease, cardiovascular disease, and all causes in the Whitehall Study. J Clin Epidemiol 1988, 41:251-260

11. Gulsvik A, Hansteen V, Sivertssen E: Cardiac arrhythmias in patients with serious pulmonary diseases. Scand J Respir Dis 1978, 59:154-159.

12. Mannino DM, Watt G, Hole D, Gillis C, Hart C, McConnachie A, Davey Smith G, Upton M, Hawthorne V, Sin DD, Man SF, Van Eeden S, Mapel DW, Vestbo $\mathrm{J}$ : The natural history of chronic obstructive pulmonary disease. Eur Respir J 2006, 27:627-643

13. Hole DJ, Watt GC, Davey-Smith G, Hart CL, Gillis CR, Hawthorne VM: Impaired lung function and mortality risk in men and women: findings from the Renfrew and Paisley prospective population study. BMJ 1996, 313:711-715.

14. Cazzola M, Puxeddu E, Bettoncelli G, Novelli L, Segreti A, Cricelli C, Calzetta $\mathrm{L}$ : The prevalence of asthma and COPD in Italy: a practice-based study. Respir Med 2011, 105:386-391.
15. Executive summary of the clinical guidelines on the identification, evaluation, and treatment of overweight and obesity in adults. Arch Intern Med 1998, 158:1855-1867.

16. Jessup M, Abraham WT, Casey DE, Feldman AM, Francis GS, Ganiats TG, Konstam MA, Mancini DM, Rahko PS, Silver MA, Stevenson LW, Yancy CW: 2009 focused update: ACCF/AHA Guidelines for the Diagnosis and Management of Heart Failure in Adults: a report of the American College of Cardiology Foundation/ American Heart Association Task Force on Practice Guidelines: developed in collaboration with the International Society for Heart and Lung Transplantation. Circulation 2009, 119:1977-2016.

17. Quanjer PhH (ed.): Standardized lung function testing. Report Working Party Standardization of Lung Function Tests. European Community for Coal and Steel. Bull Eur Physiopathol Respir 1983, 19(Suppl. 5):1-95.

18. Roger VL, Go AS, Lloyd-Jones DM, Adams RJ, Berry JD, Brown TM, Carnethon MR, Dai S, de Simone G, Ford ES, Fox CS, Fullerton HJ, Gillespie C, Greenlund KJ, Hailpern SM, Heit JA, Ho PM, Howard VJ, Kissela BM, Kittner SJ, Lackland DT, Lichtman JH, Lisabeth LD, Makuc DM, Marcus GM, Marelli A, Matchar DB, McDermott MM, Meigs JB, Moy CS, et al: Heart disease and stroke statistics-2011 update: a report from the American Heart Association.

Circulation 2011, 123(suppl 4):e18-e209.

19. Mannino DM, Thorn D, Swensen A, Holguin F: Prevalence and outcomes of diabetes, hypertension and cardiovascular disease in COPD. Eur Respir J 2008, 32:962-969.

20. Schanen JG, Iribarren C, Shahar E, Punjabi NM, Rich SS, Sorlie PD, Folsom AR: Asthma and incident cardiovascular disease: the Atherosclerosis Risk in Communities Study. Thorax 2005, 60:633-638.

21. Onufrak SJ, Abramson JL, Austin HD, Holguin F, McClellan WM, Vaccarino LV: Relation of adult-onset asthma to coronary heart disease and stroke. Am J Cardiol 2008, 101:1247-1252.

22. Iribarren C, Tolstykh IV, Miller MK, Sobel E, Eisner MD: Adult Asthma and Risk of Coronary Heart Disease, Cerebrovascular Disease, and Heart Failure: A Prospective Study of 2 Matched Cohorts. Am J Epidemio/ 2012 176:1014-1024.

23. de Lucas-Ramos P, Izquierdo-Alonso JL, Rodriguez-Gonzalez Moro JM, Frances JF, Lozano PV, Bellón-Cano JM: Chronic obstructive pulmonary disease as a cardiovascular risk factor. Results of a case-control study (CONSISTE study). Int J Chron Obstruct Pulmon Dis 2012, 7:679-686.

24. Stone IS, Barnes NC, Petersen SE: Chronic obstructive pulmonary disease: a modifiable risk factor for cardiovascular disease? Heart 2012, 98:1055-1062

doi:10.1186/2049-6958-8-58

Cite this article as: Bellocchia et al:: Predictors of cardiovascular disease in asthma and chronic obstructive pulmonary disease. Multidisciplinary Respiratory Medicine 2013 8:58.

\section{Submit your next manuscript to BioMed Central and take full advantage of:}

- Convenient online submission

- Thorough peer review

- No space constraints or color figure charges

- Immediate publication on acceptance

- Inclusion in PubMed, CAS, Scopus and Google Scholar

- Research which is freely available for redistribution

Submit your manuscript at www.biomedcentral.com/submit
C Biomed Central 